\title{
THE STUDY OF INDOOR MICROCLIMATE ON WOODEN CHURCHES TO BE INCLUDED AMONG ORADEA'S REPRESENTATIVE SIGHTS
}

\author{
Dana Carmen MIHINCĂU (MIHELE)* \\ University of Oradea, Department of Geography, Tourism and Sports, \\ 1 University Street, 410 087, Oradea, Romania, e-mail: danamihincău@gmail.com

\section{Dorina Camelia ILIES} \\ University of Oradea, Faculty of Geography, Tourism and Sport, \\ 1 University Street, 410 087, Oradea, Romania, e-mail: iliesdorina@yahoo.com

\section{Yulia KOROLEVA} \\ Immanuel Kant Baltic Federal University, Ulitsa Aleksandra Nevskogo, 14, \\ Kaliningrad, Kaliningradskaya oblast', Rusia, e-mail: yu.koroleff@yandex.ru

\section{Grigore Vasile HERMAN} \\ University of Oradea, Faculty of Geography, Tourism and Sport, \\ 1 University Street, 410 087, Oradea, Romania, e-mail: grigoreherman@yahoo.com
}

Citation: D.C., Mihincău (Mihele), Ilieș, D. C., Koroleva, Y., \& Herman, G. V. (2019). THE STUDY OF INDOOR MICROCLIMATE ON WOODEN CHURCHES TO BE INCLUDED AMONG ORADEA'S REPRESENTATIVE SIGHTS. GeoJournal of Tourism and Geosites, 26(3), 737-750. https://doi.org/10.30892/gtg.26305-393

\begin{abstract}
The current theoretical and experimental study, on microclimate regarding wooden churches currently not listed as historic monuments, but which may in future be included among the top touristic sights of Oradea, aims to highlight the particularities of indoor microclimate in these wooden churches of the city of Oradea and the way that microclimate may be influenced by religious activities, by the number of worshippers, and by that of visitors. For the purposes of this study we used data on temperature, relative humidity and $\mathrm{CO} 2$ using the thermohygrometers KlimaLogg Pro and Trotec BZ30. The three wooden churches of Oradea currently not officially recognized as historic monuments but which, in future, due to their beautiful traditional wood architecture reminiscent of older churches, and to the great number of paintings and religious icons adorning them, may be deemed historic monuments, valorized thought tourism. The analysis of the obtained data reveals that there can be no optimal indoor microclimate inside these churches. DM 10/2001 recommends relative humidity of $45 \%-60 \%$ and temperatures between $6^{\circ} \mathrm{C}$ and $25^{\circ} \mathrm{C}$, ideally of $25^{\circ} \mathrm{C}$, so that structural damage should be avoided. On the other hand, thermal comfort for the population attending religious service or merely visiting should consist of temperatures between $17^{\circ} \mathrm{C}$ and $24^{\circ} \mathrm{C}$ and humidity of $45 \%-55 \%$, in accordance to the regulations in force in Romania. In certain areas in the churches
\end{abstract}

\footnotetext{
* Corresponding author
} 
conditions do fall within the intervals recommended by the norms in force for health and hygiene and by the standards regarding microclimatic risk factors for wooden constructions. Yet this is only briefly, due to ventilation ensured by the opening of doors and windows, as well as, in one of them, by an air conditioning system.

Key words: air temperature, $\mathrm{CO} 2$, indoor microclimate, Oradea, relative humidity, wooden church, tourism

\section{INTRODUCTION}

This study may prove useful for both parishioners, priests carrying out activities in those churches, as well as for tourists visiting Oradea, and particularly its churches, outstanding due to their style and architecture and which, alongside other historically and architecturally important buildings, constitute tourist landmarks. The first significant buildings of the city of Oradea were its places of worship. Recently there have been a fair few churches built in the city. Statistically speaking, there is a place of worship for every 3,000 inhabitants. The first church is built in the Olosig area in 1693.

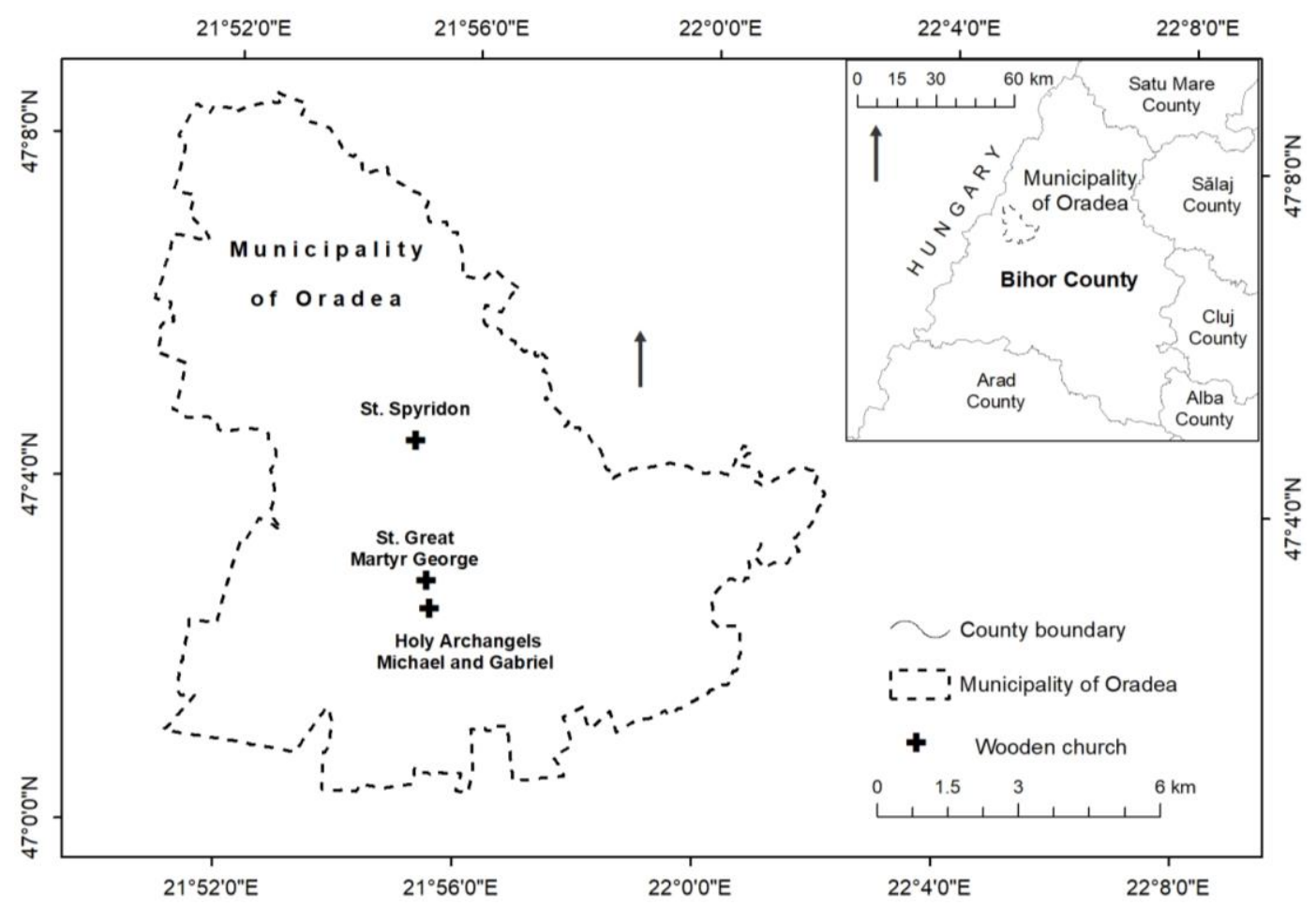

Figure 1. Location of the wooden church in Oradea, Bihor County

It initially belonged to Roman-Catholics and was called St. Brigitta's Church; now it belongs to the Orthodox community, as the Holy Trinity Church. Several other places of worship were erected later, some of which exist to this day, such as the RomanCatholic St. Ladislaus Church, and the Orthodox churches of the Dormition ("The 
The Study of Indoor Microclimate on Wooden Churches To Be Included Among Oradea's Representative Sights

Church with the Moon"), and of the Annunciation. At present, Oradea, given its population of approximately 200,000 inhabitants, may be called a genuine "city of churches," of which there are roughly 6o, including prayer houses and synagogues.

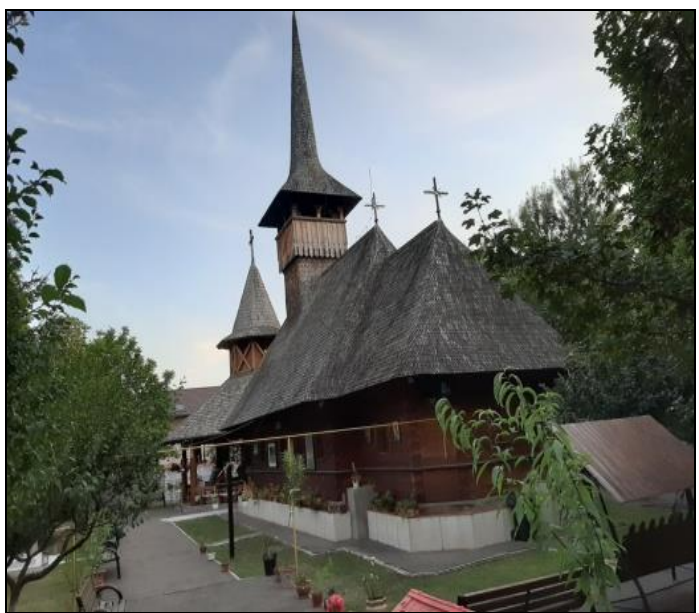

Figure 2. St. Great Martyr George wooden church of Oradea, Bihor County, exterior (2019)

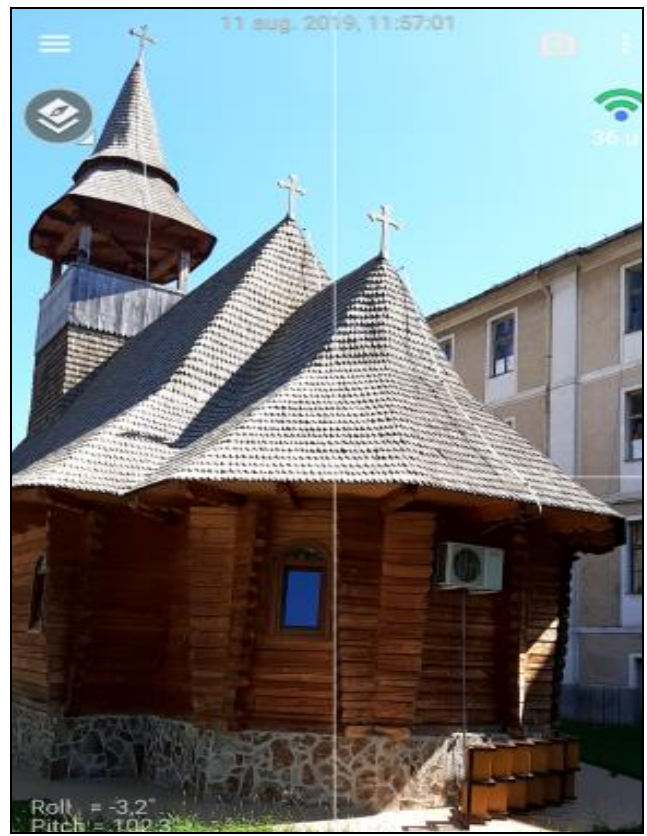

Figure 4. The Holy Archangels Michael and Gabriel Church of Oradea, Bihor County, exterior (2019)

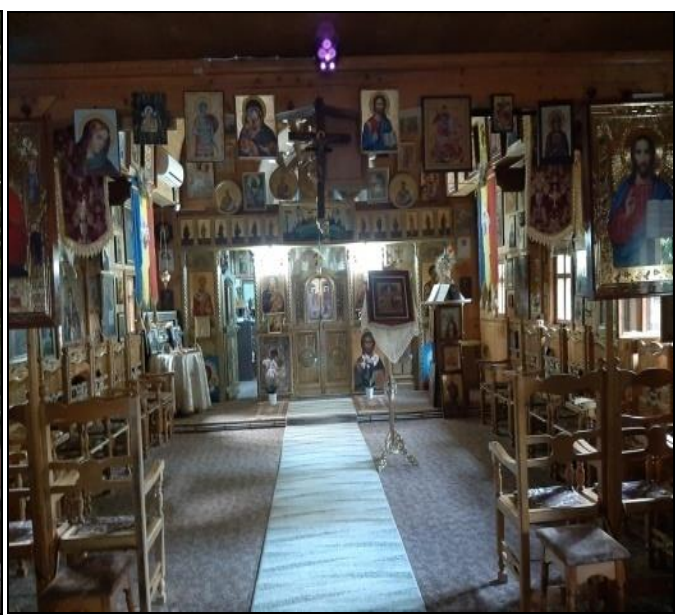

Figure 3. St. Great Martyr George wooden church of Oradea, Bihor County, interior (2019)

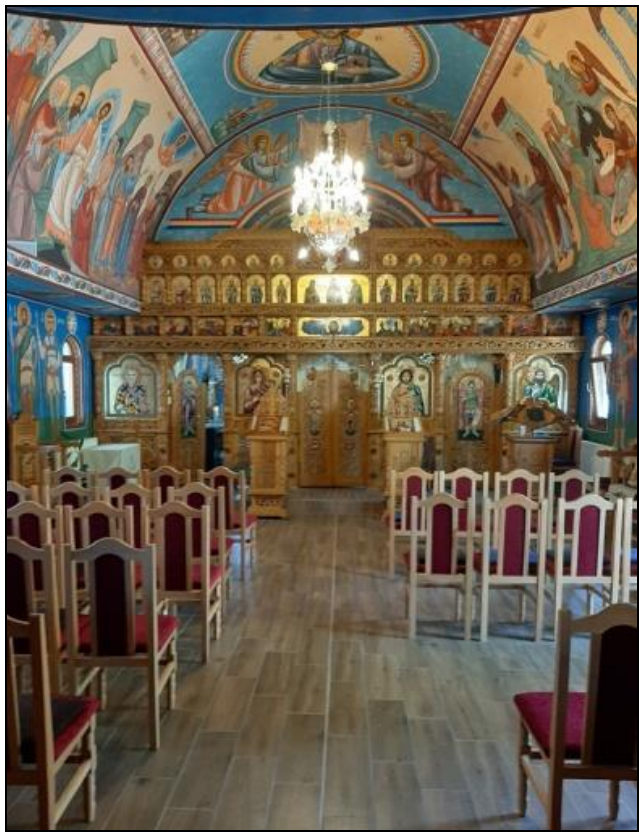

Figure 5. The Holy Archangels Michael and Gabriel Church of Oradea, Bihor County, interior (2019)

This is due to the high number of religions and denominations found in the city: Christianity (Eastern Orthodox; Roman-Catholics; Greek-Catholics; Protestants, such as the Reformed; Neoprotestants, such as the Baptists and the Pentecostals), Judaism (Orthodox 
as well as Neolog branches), Islam, etc. Most places of worship, 21, belong to the majoritarian Orthodox denomination; of these, 13 are already built, 7 are undergoing construction, and 1 is in its design phase. The Baptist and Pentecostal Christian denominations have, respectively, 10 and 12 places of worship, though they have fewer parishioners. The Greek-Catholic denomination has 3 churches, and the Jewish denominations have 3 synagogues. Besides the famous large churches, which draw in large numbers of the faithful and an increasing number of tourists on a daily basis, small wooden churches also exist; they are less showy but they are reminders of the traditional wooden architecture of the Romanian people. Oradea has three such wooden churches, built in specific locations and for specific aims, intended to serve a small number of attendants. Such precise aims are as follows: the military church doubly dedicated to the Ascension of the Lord and the Holy Great Martyr George and found in the Oradea garrison was intended for military personnel (Figure 2 and 3); the church dedicated to Archangels Michael and Gabriel, who are also considered patrons of the Romanian Gendarmerie (Figure 4 and 5), was erected in the courtyard of the County Gendarmerie Inspectorate on Universităţii street; while the little church in the courtyard of the Dr. Gavril Curteanu Municipal Clinical Hospital, dedicated to Saint Spyridon (Figure 6 and 7), for the parents whose children are admitted to the hospital for various medical issues. At present, the number of those attending these churches has considerably increased and diversified, as these churches have become open to many other Orthodox in the city who come here for solace and quiet reflection.

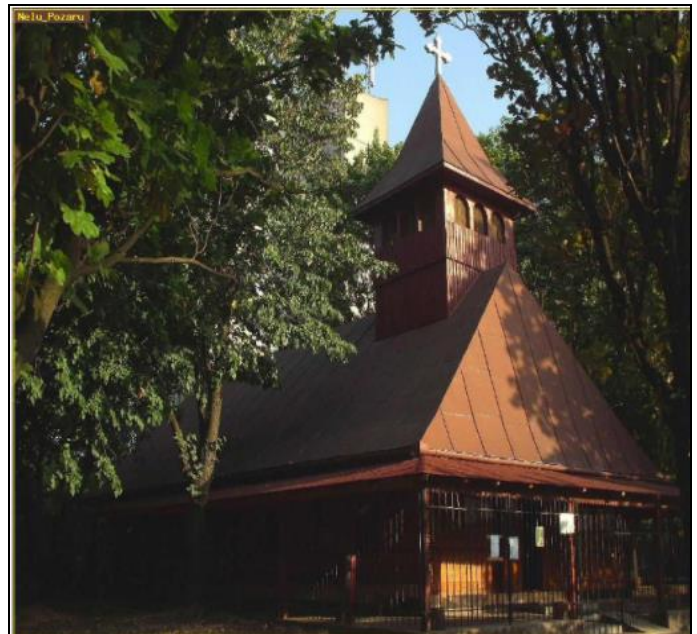

Figure 6. The St. Spyridon Church of Oradea, Bihor County, exterior (2019)

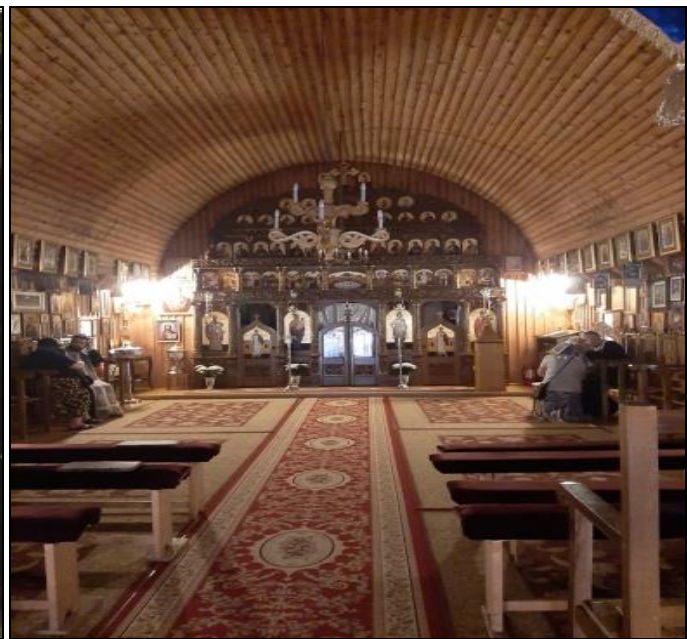

Figure 7. The St. Spyridon Church of Oradea, Bihor County, interior (2019)

\section{MATERIALS AND METHODS}

The first stage of this research involved the consulting of articles and papers focusing on the study of indoor microclimate in churches in general, and of wooden churches in particular (Ilieș et al., 2016; 2018a,b; García et al., 2013; Gozner, et al., 2016; Baias et al., 2015; Hudisteanu et al., 2014; Mihăilescu et al., 2002; Necula, 2016; Rosin et al., 2014; Sadłowska et al., 2014; Seppänen et al., 2006; Simileanu et al., 2006; Varas-Muriel et al., 2014; Vasilescu, 2016). Field research has also been carried out to also obtain technical information on churches from the priests serving there, as well as on the number of visitors interested in these specifically Romanian buildings. Data 
processing and analysis, the second stage of this research, is based on data yielded by measurements conducted in the interval August 5-15, 2019 in the three wooden churches of Oradea using as measuring devices the Trotec BZ 30 and the KlimaLogg Pro thermohygrometer with 8 external sensors, as well as data on the feasibility of including these three churches on sightseeing tours. Thus we were able to analyze indoor microclimate according to the values of temperature, relative humidity, and $\mathrm{CO}_{2}$ in all three churches, as well as at various places inside the churches, such as the altar, the nave, the narthex, and the steeple. Added to the values yielded by the measured data were the outdoor weather factors, which play an important part in the daytime analysis of indoor microclimate; the construction factor (building type, size, and material for each church); the human factor, with considerable influence on aspects of the microclimate all during service hours; and the churches' means of heating, ensuring the balance between conservation and thermal comfort (Ilieș et al., 2018c; Indrie et al., 2019).

The data obtained via measurements allow for the identification of optimal conditions in accordance to international and national standards on indoor microclimate (EN-15251:2012, EN-15241:2011, EN-15242:2009 şi EN-13779:2008, ASHRAE 62.12013), and for the identification of conditions less optimal, thus which do not fall within the standard intervals. Concerning the analysis of those indoor microclimate characteristics, we attest to the obtained values correlating with those established as optimal by standards regarding microclimate factors adopted in Romania, as well as in accordance to the regulations in force and which recommend that temperatures be between $17^{\circ} \mathrm{C}$ and $24^{\circ} \mathrm{C}$, while relative humidity between $45 \%$ and $55 \%$ to achieve adequate indoor thermal comfort (Law SSM no. 319/2006). Buildings have international recommendations on temperature and relative humidity (UNI 10829: $10-24^{\circ} \mathrm{C}$ and $55 \%$ 65\%; and DM 10/2001: 6- $25^{\circ} \mathrm{C}$, ideal recommendation: $25^{\circ} \mathrm{C}$, and $\left.45 \%-60 \%\right)$, so there are certain measures proposed as necessary for keeping an optimal climate within such wooden churches, for the sake of both the structures themselves and the population visiting them (Mihăilescu et al., 2002).

\section{RESULT DISCUSSION}

As the urban architecture of Oradea is highly diverse, with the city permanently evolving, these wooden churches become ever more cramped among the high-rise buildings put up near them. This is indeed the case of the church in the courtyard of the hospital on Corneliu Coposu street, which is very difficult to locate as it is inadequately marked and visually dominated by the multilevel parking complex built in its immediate vicinity. The very access to the church is in fact limited by the wall of the parking complex. Not the same can be said about the wooden church within the Oradea garrison, which enjoys a small but inviting courtyard among the buildings of the former military units, some of which are in a marked state of disrepair. Ventilation is better here due to the air flow unimpeded by the proximity of any nearby high-rises.

The church in the courtyard of the County Gendarmerie Inspectorate on Universităţii Street also does not have too vast a space to call its own, which is why its construction was atypical for Orthodox churches, so as its placement required special dispensation from the Patriarchy. All Orthodox churches have their altar facing east, yet this one has its altar facing south-west on account of insufficient space, as it is surrounded by gendarmerie buildings. We could also note here that the indoor space is easier to air and ventilate due to the better air flow resulting from the low density of tall buildings in the area (Hudisteanu et al., 2014). As we visited them and participated in the religious services in order to conduct measurements specific to their indoor climate, 
we could draw the conclusion that the church in the courtyard of the Gendarmerie is the one least frequented by worshippers and tourists, which is likely due to the more restricted access to the inside of the Gendarmerie's compound, or perhaps also to its location in a non-residential area. The church in the hospital's courtyard is found in a highly populated neighborhood, with many apartment buildings nearby, which renders it crowded during Sunday service and on main religious holidays, especially as it has become a parish church. The military church is also relatively well attended, as it is known by many people since service is held there fairly frequently and regularly, but also because it holds occasional cultural-religious or memorial events.

We monitored their microclimate to make sure that these wooden churches last for centuries and that we gain the ability to control their indoor climate, such that religious service and organized visits for groups or individuals occur under better circumstances and the attending population may benefit from satisfactory climate comfort.

Our monitoring aimed to identify their indoor microclimate characteristics based on values for air temperature, relative humidity, and $\mathrm{CO}_{2}$ (Onet et al., 2018; García et al., 2013).

To obtain this information, we set up the two measuring devices, the Trotec BZ 30 and the KlimaLogg Pro thermohygrometer with 8 external sensors.

\section{The wooden church doubly dedicated to the Ascension of the Lord and the St. Great Martyr George in the Oradea garrison}

The „military, church in the Oradea garrison, under the command of the Bihor County Military Center (Figures 2 and 3), was erected to cater for the spiritual needs of the military personnel and staff and their families, as well as those of all worshippers crossing its doorstep on Sundays and holidays and, more recently, of any occasional visitors to the area on their travels through the city. The church was built in 2001 within the short timespan of three months (Feb. 1-April 23) mainly out of fir wood, with bracing structures out of oak (such as the beams and the support girders on the porch and in the steeple); its foundation is out of concrete and the floorboards are wooden. The roof consists of fir wood shingles; the iconostasis and all the furniture are oaken. It is $23 \mathrm{~m}$ long, $5.8 \mathrm{~m}$ wide and $23 \mathrm{~m}$ tall to the top of the cross; its useful surface is $72 \mathrm{~m}^{2}$, with an additional $100 \mathrm{~m}^{2}$ for the summer altar, an extension of the porch closed with stainedglass windows. The church also has two bells, one weighing $150 \mathrm{~kg}$ and the other, $90 \mathrm{~kg}$, both operated electronically. During winter heating is ensured via the city's gas mainframe, using radiators. Inside, the church is adorned with wood-painted, clothpainted, and glass-painted religious icons (Figure 2). The measuring devices were in place between August 5, 2019 (7:05 pm) and August 6, 2019 (12:40 pm) and taken away at the end of the Feast of the Transfiguration service, when only around 30 people attended liturgy as it was a work day, during the work week. Information we obtained from the parish priest indicates that on Sundays an average of 80-100 people attend service.

The interpretation of the obtained data shows that the indoor average air temperature was between $24.4^{\circ} \mathrm{C}$ (in the narthex) and $25.6^{\circ} \mathrm{C}$ (in the altar). The highest indoor air temperature was $31.2^{\circ} \mathrm{C}$, recorded on August 7, 2019 at $6: 30$ in the church steeple. In contrast, the lowest indoor air temperature was $19.9^{\circ} \mathrm{C}$, recorded on August 6, 2019 at $0: 00$ am (Figure 1). Based on the recorded data, average relative humidity varied between $62 \%$ in the narthex and $52 \%$ in the altar (Figure 6). The highest value for relative humidity was $66 \%$, recorded on August 6, 2019 at 8 am, while the lowest was $44 \%$, also recorded on August 6, 2019 at $5 \mathrm{pm}$. Given temperatures of $18-20^{\circ} \mathrm{C}$, relative humidity must be $60 \%$, and for temperatures of $24-25^{\circ} \mathrm{C}$ it should only be at $40 \%$ for the experience of thermal comfort. High relative humidity is conducive to the development of microbial flora and damages furniture, particularly the wooden pieces. According to Government 
Resolution no. 1546/2003, temperatures inside buildings housing heritage assets must not exceed $22^{\circ} \mathrm{C}$, also depending on relative humidity, which should be between $50 \%$ and $65 \%$. We can adapt this ruling to wooden churches that happen not to be historic monuments but where we wish to see optimal conditions for the conservation of existent assets (Necula, 2016; Rosin et al., 2014). The analysis of the yielded results clearly shows that the church does not fulfill the basic necessary conditions to ensure an optimal microclimate for the population or the wooden church itself (Sadłowska et al., 2014).

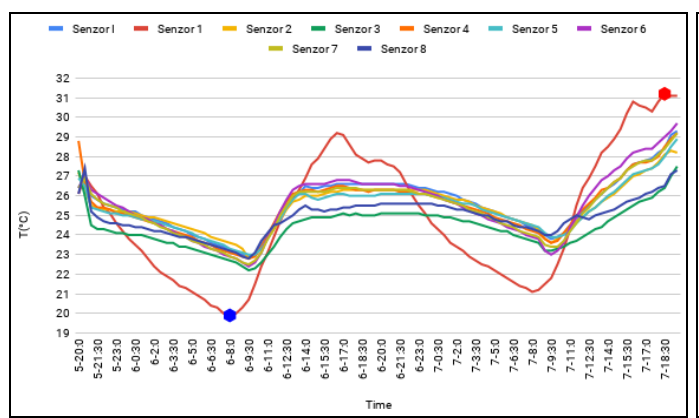

Figure 8. Temperature values recorded in the interval August 5-7, 2019 in the St. George church of Oradea

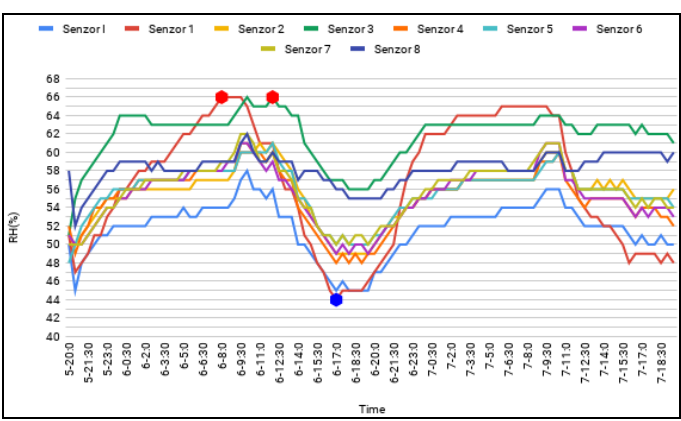

Figure 9. Relative humidity values recorded in the interval August 5-7, 2019 in the St. George church of Oradea

During the August 6 service, the data recorded between 9 am and 12:50 pm (Figure 10) show that temperatures vary from $23.7^{\circ} \mathrm{C}$ at 9 a.m. to $28^{\circ} \mathrm{C}$ at $12: 40$ p.m., which are values over the normal indoor air temperature limits, in accordance to the regulations in force in Romania recommending temperatures between $17^{\circ} \mathrm{C}$ and $24^{\circ} \mathrm{C}$ to achieve adequate indoor thermal comfort. Relative humidity values registered a downward trend as the air warmed up, with variations between $55 \%$ at 9 a.m. and $46 \%$ at 12:50 p.m. Given that optimal indoor comfort requires humidity values to fall between $45 \%$ and 55\%, we see that optimal conditions are met here. On August 6, 2019 (Figure 11), CO2 values varied from $381 \mathrm{ppm}$, the minimum value recorded at 9:05 a.m., to $652 \mathrm{ppm}$, the maximum value recorded at 10:50 a.m. The recorded values are optimal according to the health and hygiene norms in force (Hurezeanu, 2008).

\section{The wooden church in the courtyard of the County Gendarmerie Inspectorate}

The information provided by the church's priest reveals that construction began on March 19 and ended on November 2. Its placement is different to that of the other Orthodox churches, and it is built out of spruce, with a concrete foundation and floors out of wood-imitation sandstone. The roof consists of spruce shingles, the iconostasis and the furniture are made of oak, and its seats made of beech. The inner walls are decorated with frescoes painted using natural dyes on a foundation of lime and tow, overlaid directly on the wood with a supporting wire mesh (Figures 4 and 5). The church has an electronic sound system instead of bells, a choice selected in order to avoid trepidations that would risk deteriorating the painting. It is $17 \mathrm{~m}$ long, $7 \mathrm{~m}$ wide, and $19 \mathrm{~m}$ tall to the tip of the cross on the steeple. Its surface is $118 \mathrm{~m}^{2}$. This church has two doors, one in the narthex, at the back of the church, and the other in the nave, on its right. Services held on Sundays and religious festivals throughout the year gather approximately 30-50 people on average.

The measuring devices were in place between August 8, 2019 (8:20 am) and August 11, 2019 (11:50 am), till the end of Sunday Mass, which was attended by some 20 people. 


\section{Dana Carmen MIHINCĂU (MIHELE), Dorina Camelia ILIES, Yulia KOROLEVA, Grigore Vasile HERMAN}

The interpretation of the yielded data shows, as seen on Figure 11, that the average indoor air temperature ranged between $24.4^{\circ} \mathrm{C}$ (recorded in the narthex) and $25.6^{\circ} \mathrm{C}$ (in the steeple). The highest indoor temperature was $27.8^{\circ} \mathrm{C}$, recorded on August 11, 2019 at $1 \mathrm{pm}$ inside the nave, where the majority of worshippers were found. In contrast, the lowest air temperature value was $21.9^{\circ} \mathrm{C}$, also recorded on August 11, 2019 at 10:30 am (Figure 9), inside the altar due to the air conditioning system having been turned on.

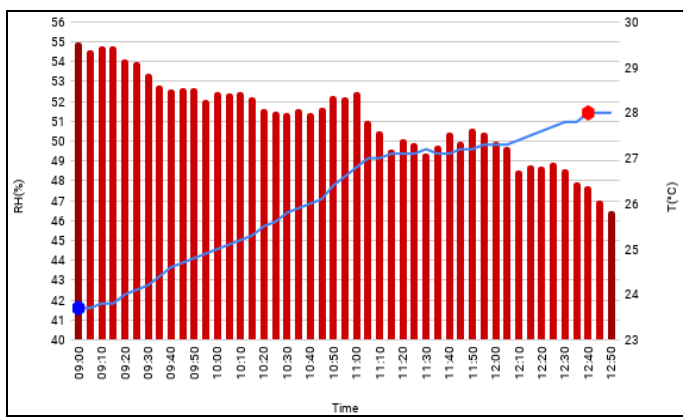

Figure 10. Temperature and relative humidity variations recorded on August 6, 2019 in the St. George church of Oradea

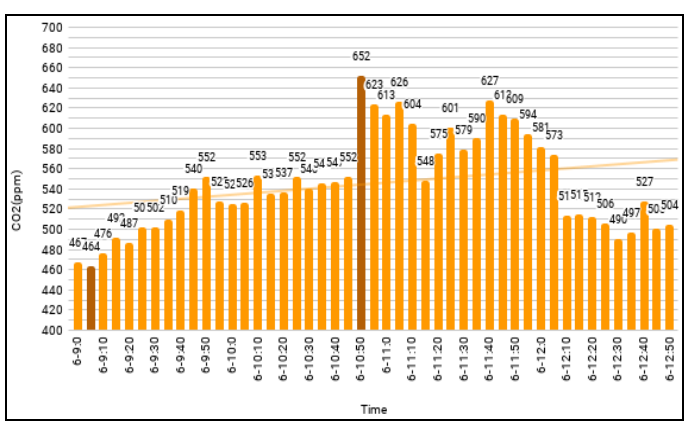

Figure 11. $\mathrm{CO}_{2}$ variations recorded on August 6, 2019 in the St. George church of Oradea

As seen on Figure 13, the analyzed data shows that average relative humidity fell between $68 \%$ in the narthex and $54 \%$ in the altar. The highest relative humidity value was $72 \%$, noted on August 8, 2019 at 2:30 pm, while the lowest was 54\%, spotted on August 11,2019 at $1 \mathrm{pm}$. The church registered values slightly over the normal limits of temperature and relative humidity, in accordance to ISO 16814:2008, ISO 7730: 2006, SR EN 12792:2004, and the regulations in force in Romania, Law no. 263 of July 19, 2007 prescribing relative humidities between $55 \%$ and $65 \%$ and temperatures between $10^{\circ} \mathrm{C}$ and $24^{\circ} \mathrm{C}$ in order to ensure adequate indoor thermal comfort *** (2007).

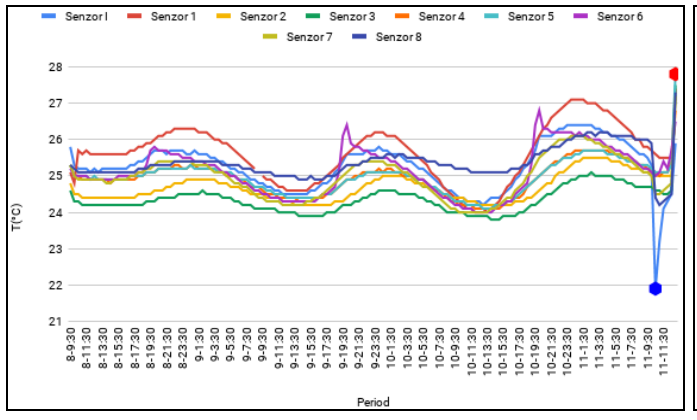

Figure 12. Temperature values recorded in the interval August 8-11, 2019 in the St. Michael and Gabriel church of Oradea

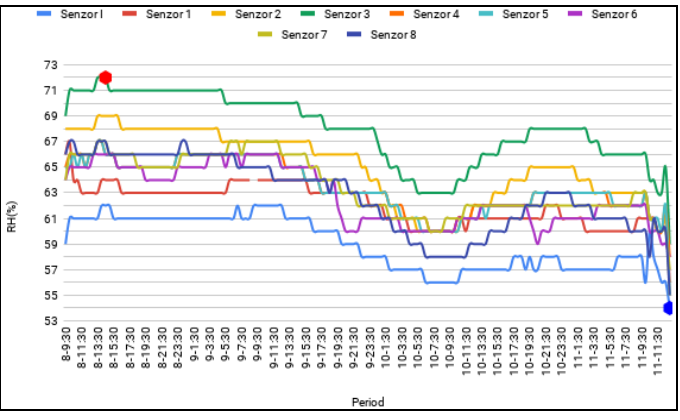

Figure 13. Relative humidity values recorded in the interval August 8-11, 2019 in the St. Michael and Gabriel church of Oradea

During the August 11 service, based on the data recorded between 8 a.m. and 11:50 a.m., it became apparent that, as seen on Figure 14, temperature values range between $25.5^{\circ} \mathrm{C}$ at 9:30 am and $26.1^{\circ} \mathrm{C}$ at $11: 45 \mathrm{am}$. Such values are slightly over the normal limits for indoor air temperature, in accordance to regulations in force in Romania prescribing temperatures between $17^{\circ} \mathrm{C}$ and $24^{\circ} \mathrm{C}$ for adequate indoor thermal comfort. Relative 
humidity values registered a downward trend, as seen on Figure 15: as the air warmed up, they decreased from $57 \%$ at 9 am to $53 \%$ at $11: 45$ am. Given that, for optimal indoor comfort levels the humidity must be between $45 \%$ and $55 \%$, we may conclude that at this location the optimal conditions are met, with a maximum slightly in excess but still fitting the 50\%-65\% interval required for wooden buildings. On August 11, 2019 the $\mathrm{CO} 2$ values varied from $467 \mathrm{ppm}$, the minimum recorded at 8:55:40 a.m. and at 9:00:40 a.m., to 824 $\mathrm{ppm}$, the maximum recorded at 11:30 a.m. These recorded values are optimal, in accordance to the health and hygiene norms in force (Hurezeanu, 2008).

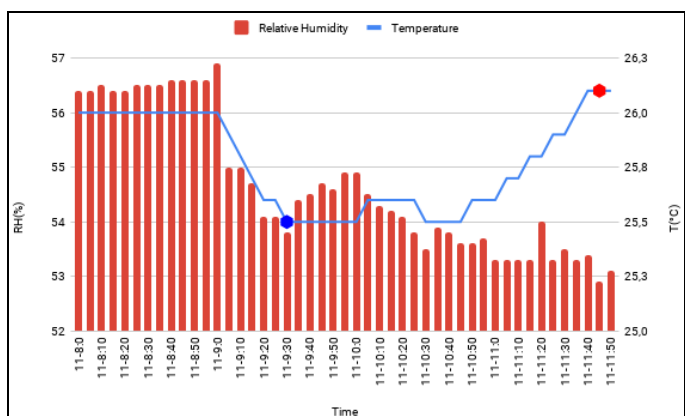

Figure 14. Temperature and relative humidity variations on August 11, 2019 in the St.

Michael and Gabriel wooden church of Oradea

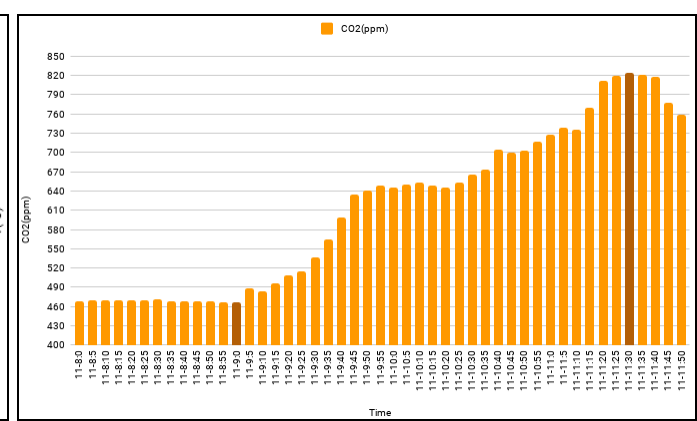

Figure 15. $\mathrm{CO}_{2}$ variations recorded on August 11, 2019 in the St. Michael and Gabriel wooden church of Oradea

\section{The wooden church in the courtyard of the Dr. Gavril Curteanu Municipal Clinical Hospital, dedicated to St. Spyridon}

The church was built in 2003 out of fir wood; its foundation is concrete and its roof is tin, painted brick red. The floor is made of laminated floorboards, and its furniture and its iconostasis are made of stained fir. The church is $20 \mathrm{~m}$ long, $7 \mathrm{~m}$ wide, and it has bells.

Its architecture is simple, minimalistic, giving a provisional feeling as it was conceived of as a chapel for praying on hospital grounds, for the benefit of the admitted patients (Figure 4). The church has three doors, one in the narthex, at the back, another one to the left of the nave, and the third in the altar. It is decorated with icons donated by the faithful (Figures 6 and 7). The measuring devices were in place between August 12, 2019 at 7 pm and August 15, 2019 at 12 pm, until the end of the religious service for the Dormition Feast (August 15), at which point the church was full of worshippers.

The interpretation of the recorded data reveals, as seen on Figure 16, that air temperatures averaged between $25.2^{\circ} \mathrm{C}$ (recorded in the narthex) and $26.4^{\circ} \mathrm{C}$ (in the nave, particularly near the lectern, where the cantors are). The highest indoor air temperature was $33.1^{\circ} \mathrm{C}$, recorded on August 12, 2019 at 7 p.m. on the left-hand side of the nave, where the casket containing the holy relics is located, such that people come to worship them at the end of service. The same was true for the altar, where the thurible and the candles that had been burning during liturgy also had an influence. On the other hand, the lowest air temperature was $19.5^{\circ} \mathrm{C}$, also recorded on August 15, 2019 between 9 a.m. and 9:30 a.m. (Figure 16), in the narthex, near the entrance door. As Figure 17 indicates, the analysis of the recorded data reveals that average relative humidity was between $64 \%$ in the narthex and $56 \%$ in the altar. The highest relative humidity was of $70 \%$, recorded on August 14, 2019 at 4:30 p.m. and 6:30 p.m., whereas the lowest was of 47\%, on August 12, 2019 at 7 p.m. in the altar, at floor level. The church thus registered values much over the normal limits for indoor air temperature, as per ASHRAE 62.1-2013, ASHRAE 55: 2004, and in 
accordance to the regulations in force in Romania, namely the Law no. 319/2006 recommending between $17^{\circ} \mathrm{C}$ and $24^{\circ} \mathrm{C}$ for adequate indoor thermal comfort. For optimal comfort levels inside the church, indoor humidity should be between $45 \%$ and $55 \%$, while here it exceeds those values, therefore failing to comply with the interval recommended by legislation in force, EN-15251:2012, ISO 16814:2008, and ISO 7730:2006.

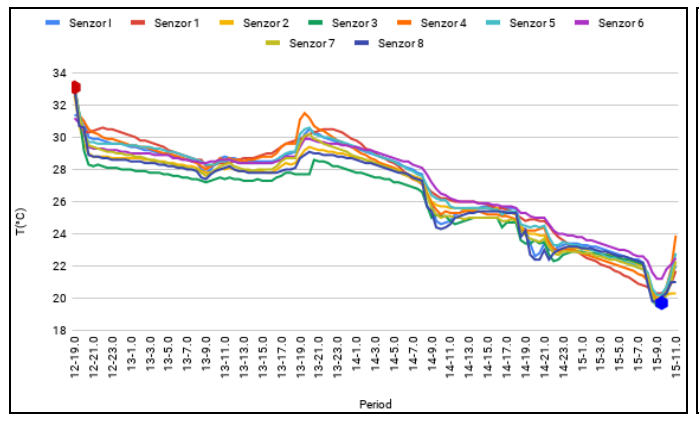

Figure 16. Temperature values recorded in the interval August 12-15, 2019 in the St. Spyridon church of Oradea

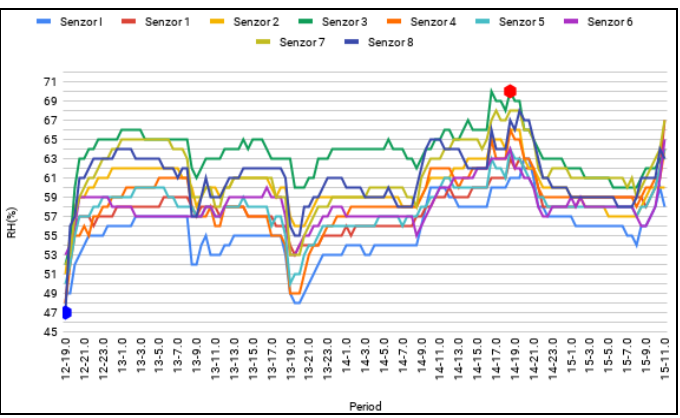

Figure 17. Relative humidity values recorded in the interval August 12-15, 2019 in the St. Spyridon church of Oradea

On August 12, 2019 (during vesper in the Assumption Fast), based on the measurements taken between 5:55 p.m. and 8:23 p.m. (Figure 18), it was visible that temperature values decreased from the maximum of $33.4^{\circ} \mathrm{C}$ at $6 \mathrm{pm}$ to $30.3^{\circ} \mathrm{C}$ at $8: 33$ p.m. These values far exceed the normal limits for indoor air temperature, as per ASHRAE 62.1-2013, ASHRAE 55: 2004, EN-15251:2012, ISO 16814:2008, ISO 7730:2006, which recommend an interval from $17^{\circ} \mathrm{C}$ to $24^{\circ} \mathrm{C}$ for the attainment of adequate indoor thermal comfort. Relative humidity values (Figure 19) registered an upward trend as the air cooled, such that they varied from $43 \%$ at 5:55 p.m to $53 \%$ at 8:23 p.m. Given that humidity must be between $45 \%$ and $55 \%$ for optimal indoor comfort levels, we may conclude that the optimal conditions are met here, with an insignificant decrease relative to the minimum point.

On August 12, $2019 \mathrm{CO}_{2}$ values vary from $475 \mathrm{ppm}$, the minimum reached at 5:55 $\mathrm{pm}$, to $820 \mathrm{ppm}$, the maximum reached at 6:53 p.m. Thus the recorded values are optimal, in accordance to the health and hygiene norms in force, EN-15251:2012, EN15241:2011, EN-15242:2009, EN-13779:2008, and ASHRAE 62.1-2013.

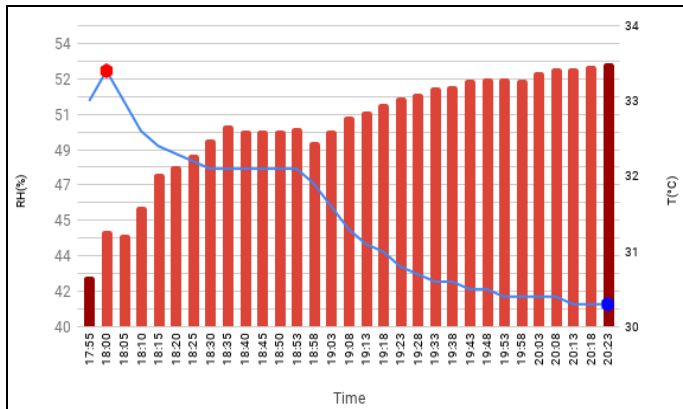

Figure 18. Temperature and relative humidity variations on August 12, 2019 in the St. Spyridon wooden church of Oradea

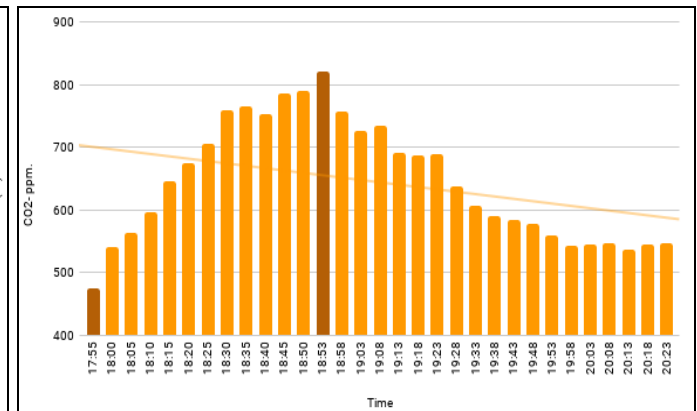

Figure 19. $\mathrm{CO} 2$ variations on August 12, 2019 in the St. Spyridon wooden church of Oradea 


\section{Interpretation of the data in a comparative view of all three churches}

The minimum values recorded in the three monitored churches fall inside the optimal interval $\left(17^{\circ} \mathrm{C}-24^{\circ} \mathrm{C}\right)$ recommended by EN-15251:2012, EN-15241:2011, EN-15242:2009, EN13779:2008, and ASHRAE 62.1-2013 for adequate indoor thermal comfort.

The lowest minima for air temperature in the three churches (Figure 20) are very close together, ranging from $19.5^{\circ} \mathrm{C}$ in the narthex of the St. Spyridon church to $19.9^{\circ} \mathrm{C}$ in the steeple of the St. George church and to $21.9^{\circ} \mathrm{C}$ in the altar of the St. Michael and Gabriel church. The highest minima also vary in the same church order, namely $21.2^{\circ} \mathrm{C}$ at the lectern of the St. Spyridon church, $22.9^{\circ} \mathrm{C}$ in the altar of the St. George church, and $24 \cdot 2^{\circ} \mathrm{C}$ in the narthex of the St. Michael and Gabriel church.

Thus there are minor differences only in the case of the respective church areas. The lowest minima for relative humidity in the three churches (Figure 21) are very close together just as the case of temperatures has been. $44 \%$ in the steeple of the St. George church, $47 \%$ in the altar of the St. Spyridon church, and $54 \%$ in the altar of the St. Michael and Gabriel church all fall inside the interval recommended as optimal according to EN15251:2012, EN-15241:2011, EN-15242:2009, EN-13779:2008, and ASHRAE 62.1-2013. The highest measured minima are $52 \%$ in the altar of the St. George church, $53 \%$ in the nave-lectern area of the St. Spyridon church, and 59\% in the narthex of the St. Michael and Gabriel church. It is thus clear that these values fit in the interval considered as ensuring an optimal indoor comfort level for service participants, of $45 \%-55 \%$, as well as in the interval of 50\%-65\%, optimal for wooden structures in accordance to EN-15251:2012, EN-15241:2011, EN-15242:2009, EN-13779:2008, ASHRAE 62.1-2013, and DM 10/2001.

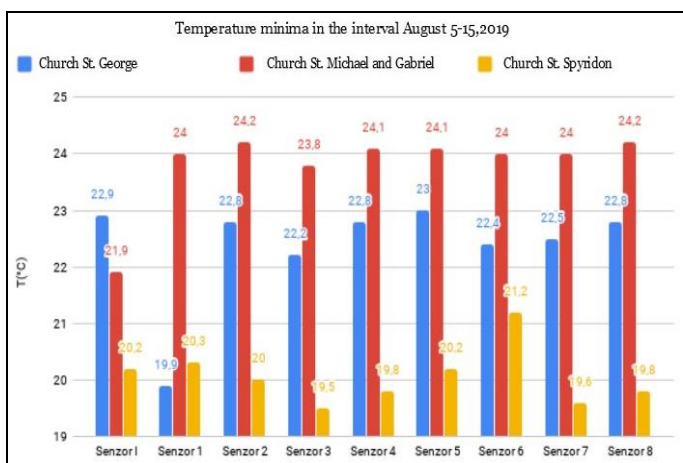

Figure 2o. Temperature minima in the interval August 5-15, 2019 in the St. George, St. Michael and Gabriel, and St. Spyridon wooden churches of Oradea

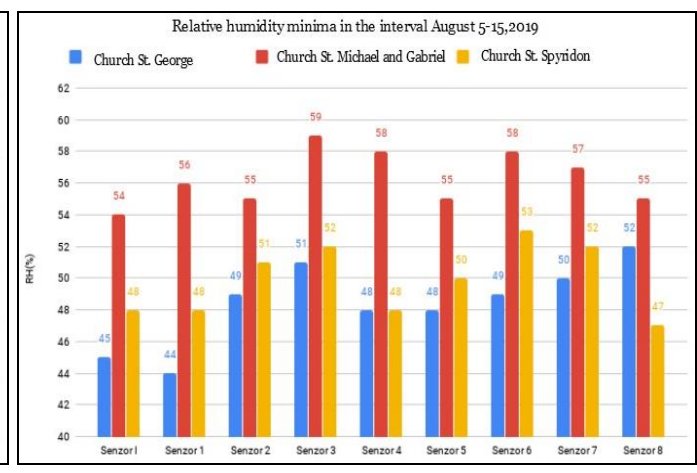

Figure 21. Relative humidity minima in the interval August 5-15, 2019 in the St. George, St. Michael and Gabriel, and St. Spyridon wooden churches of Oradea

The average values recorded in the three monitored churches fall slightly outside the optimal recommended interval of $17^{\circ} \mathrm{C}$ to $24^{\circ} \mathrm{C}$ for adequate indoor thermal comfort, in accordance to regulations in force in Romania. Average values for air temperature in the three churches (Figure 22) are very close together, ranging from $24.4^{\circ} \mathrm{C}$ in the narthex of the St. George and St. Michael and Gabriel churches, to $25.6^{\circ} \mathrm{C}$ in both the altar of the St. George church and the steeple of the St. Michael and Gabriel church, to $25.9^{\circ} \mathrm{C}$ in the narthex and respectively $27.1^{\circ} \mathrm{C}$ in the nave-lectern area of the St. Spyridon church. Thus there are minor differences only in the case of the respective church areas.

Average values for relative humidity in the three churches (Figure 23) are very close together just as the case of temperatures has been. The lowest are in the altars: $52 \%$ in 


\section{Dana Carmen MIHINCĂU (MIHELE), Dorina Camelia ILIES, Yulia KOROLEVA, Grigore Vasile HERMAN}

the St. George church, 56\% in the St. Spyridon church, and 59\% in the St. Michael and Gabriel church. The highest average values measured are also in the altars: 62\% in the St. George church, 64\% in the St. Spyridon church, and 68\% in the St. Michael and Gabriel church.

We may thus make the observation that differences are not recorded among church areas but only among churches depending on external weather factors. The recorded values exceed the values of the standards recommended for indoor humidity, 45\%-55\%, considered to ensure optimal indoor comfort, therefore the heat sensation will be intensified.

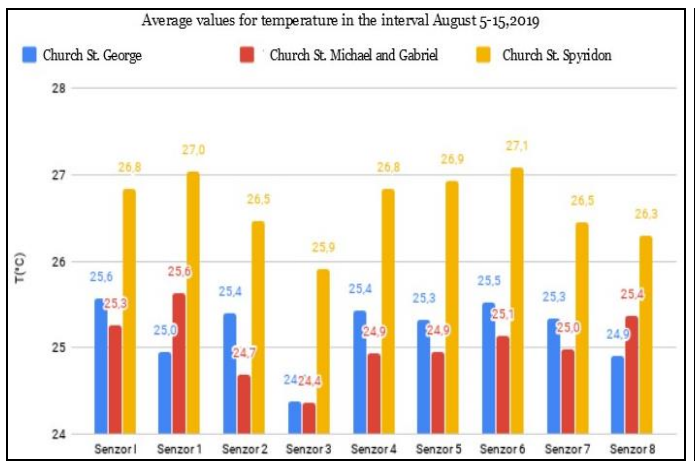

Figure 22. Average values for temperature in the interval August 5-15, 2019 in the St. George, St. Michael and Gabriel, and St. Spyridon churches of Oradea

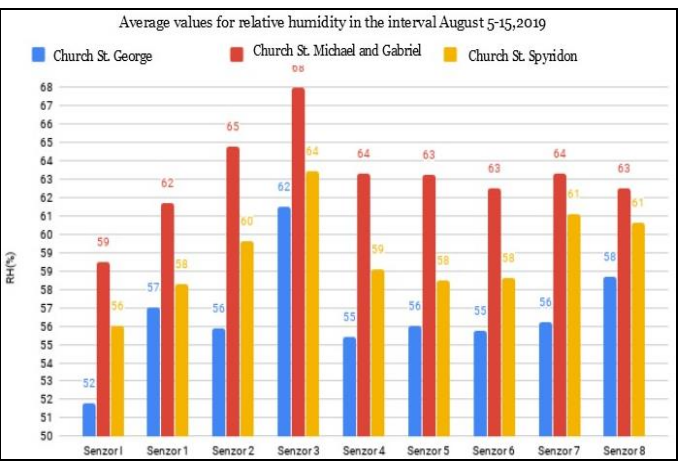

Figure 23. Average values for relative humidity in the interval August 5-15, 2019 in the St. George, St. Michael and Gabriel, and St. Spyridon churches of Oradea

The maximum values recorded in the three monitored churches fall outside the optimal interval recommended by UNI 10829 as between $10^{\circ} \mathrm{C}$ and $24^{\circ} \mathrm{C}$ (for the conservation of wooden structures) and by EN-15251:2012, EN-15241:2011, EN-15242: 2009, EN-13779:2008, and ASHRAE 62.1-2013 (for adequate indoor thermal comfort).

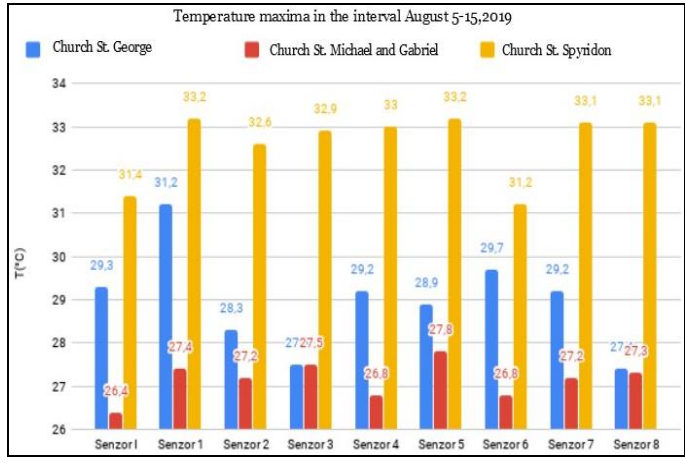

Figure 24. Temperature maxima in the interval August 5-15, 2019, in the St. George, St. Michael and Gabriel, and St. Spyridon wooden churches of Oradea

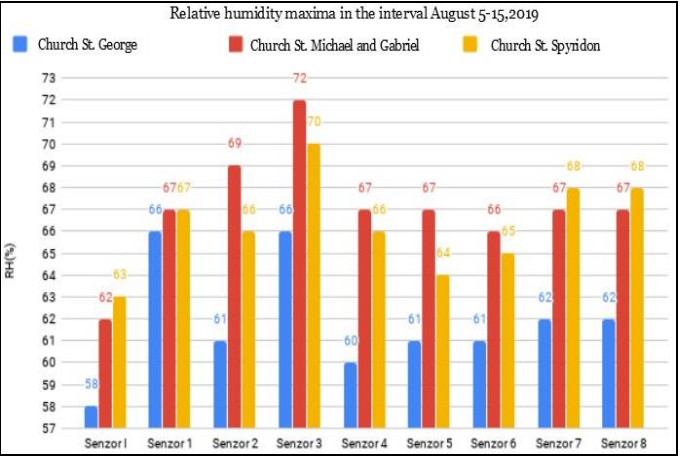

Figure 25. Relative humidity maxima in the interval August 5-15, 2019 in the St. George, St. Michael and Gabriel, and St. Spyridon wooden churches of Oradea

These obtained values ranged between $26.4^{\circ} \mathrm{C}$ and $33.2^{\circ} \mathrm{C}$, thus greatly exceeding the recommended intervals. The maximum values for air temperature in the three churches (Figure 24) differ significantly, as they vary from $26.4^{\circ} \mathrm{C}$ in the altar (high up) and $27.5^{\circ} \mathrm{C}$ in the narthex (in the St. Michael and Gabriel church) to $27.4^{\circ} \mathrm{C}$ in the altar (floor level) and 
$31.2^{\circ} \mathrm{C}$ in the steeple (in the St. George church) and to $31.2^{\circ} \mathrm{C}$ in the nave by the lectern and $33.2^{\circ} \mathrm{C}$ also in the nave but on the left, by the relics (in the St. Spyridon church). Thus we may notice that there are minor differences among churches also regarding church areas. The maximum values for relative humidity in the three churches (Figure 25) range between $58 \%$ and $72 \%$, much over the recommended interval of $45 \%-60 \%$, considered optimal for the preservation of wooden structures and for indoor comfort, as per DM 10/2001, EN-15251:2012, EN-15241:2011, EN-15242:2009, EN-13779:2008, and ASHRAE 62.1-2013. These values enhance the heat sensation inside the church and prove conducive to the development of mold even at high temperatures.

The lowest values are found in the altars: $58 \%$ in the St. George church, $62 \%$ in the St. Michael and Gabriel church, and $59 \%$ in the St. Spyridon church; while the highest values are in the narthexes: $66 \%$ in the St. George church, $70 \%$ in the St. Michael and Gabriel church, and $72 \%$ in the St. Spyridon church.

\section{CONCLUSION}

Air quality is an invisible trait, yet it has a fairly high number of ill effects on human health as well as on the structural integrity of wooden churches, provided that wood is sensitive to temperature oscillations and easily affected by microorganisms developing under conditions of high humidity. As such, it is important to maintain its quality within optimal parameters, a sure means of preventing numerous issues for both humans and the wood itself. To keep air quality within optimal intervals, we recommend centralized heating systems during winter and centralized ventilation systems during summer.

Thus we may avoid the situations uncovered by our research in these churches, namely the fact that, because of only using local fans, which cool the environment only in a small perimeter around their location (in the altar and in the nave by the lectern), there are significant differences between the spaces in use within the churches. $\mathrm{CO}_{2}$ values recorded in the three churches during religious service fall within the optimal parameters prescribed by the health and hygiene norms in force. There were no side effects to be noted since there was natural ventilation ensured during service by means of open windows and doors. Aeration is an active factor which prevents air masses stagnation and the appearance of an aggressive destructive environment in buildings. So, aeration should be inextricably linked with the design concept of the wooden church, with its composition, with the profile of the internal space and functional zoning.

Evidence of this link will allow us to reveal the preservation methods of the wooden religious buildings which were used by ancient architects, and apply them to modern works on the restoration, conservation and reconstruction of these cultural and historical monuments (Buturlintsev, 1988; Kochev, 2017). Judging by the aforementioned results and discussion, we may conclude that microclimate conditions that are optimal for the performing of religious service and tourism in the monitored interval are not met everywhere within the churches. However, we cannot refer to inadequate conditions either, as any excesses are brief and easy to control, especially should systems to monitor air quality be set up so the situation is always clear. Showcasing the wooden churches and adding them to the sightseeing tours of Oradea and Bihor County alongside the already established older wooden churches that are acknowledged as historic monuments (so tourists may compare and contrast their architectural features) should be accomplished with the support of local authorities and EU funding.

\section{Acknowledgements}

The research was possible by equal scientific involvement of all authors and acknowledge the support of the Grant PN-III-P1-1.2-PCCDI-2017-0686. 


\section{Dana Carmen MIHINCĂU (MIHELE), Dorina Camelia ILIES, Yulia KOROLEVA, Grigore Vasile HERMAN}

\section{REFERENCES}

Baias, Ș.,Gozner, M., Herman, G.V., Măduța, F.M. (2015), Typology of wooden churches in the drainage basins of Mureș and Arieș, Alba County în Analele Universităţii din Oradea, Seria Geografie, Tom XXV, Nr. 2/2015 (December), Editura Universităţii din Oradea;

Buturlintsev, V. B., (1988), The influence and role of aeration in the Russian folk wooden cult architecture of the $17^{\text {th }}-18^{\text {th }}$ centuries: The Transfiguration Church in Kizhi as an example: PH.D. dissertation: 18.00.01 - Moscow, 1988, 155 p.

García-Diego, F. J., Fernández-Navajas, Á., Beltrán, P., \& Merello, P., (2013), Study of the effect of the strategy of heating on the mudejar church of Santa Maria in Ateca (Spain) for preventive conservation of the altarpiece surroundings. Sensors, 13(9), 11407-11423.

Gozner, M., Josan I., Baias, Ș., Măduța, F.M. (2016), The Religious Attractions - An Expression of Authenticity in the Territorial System Albac - Arieşeni and Alba County (Romania), în GeoJournal of Tourism and Geosites Year IX, Volume 1, Oradea-Gdansk, Romania-Poland, Editura Universităţii din Oradea.

Hudisteanu, V. S., Baran, A. I., Balan, M., Chereches, N. C., Mateescu, T., Verdes, M., Ciocan, V., (2014), Improvement of the indoor climate conditions inside orthodox churches. International Scientific Conference CIBV, 2014, 7-8 November 2014, Braşov.

Ilies, A., Wendt, J., A., Ilieș, D., C., Ilieș, Ilieș M. \& Deac, A., L. 2016, The patrimony of wooden churches, built between 1531 and 2015, in the Land of Maramureș, Romania, Journal of Maps, Vol. 12, pp 597-602.

IIies, D. C., Onet, A., Wendt, J. A., Ilieş, M., Timar, A., Ilies, A., Baias, S. \& Herman, G. V., (2018a). Study on microbial and fungal contamination of air and wooden surfaces inside of a historical Church from Romania. Journal of Environmental Biology, 39(6), 980-984.

Ilieș, D. C., Buhaș, S, Ilieș, A., Gaceu, O. R., Oneț, A., Buhaș, S., Rahotă, D., Dragoș, P., Baiaș, Ș., Marcu, F., Oneț, C., (2018b), Indoor Air Quality Issues. Case Study: The Multipurpose Sports Hall Of The University Of Oradea. Environmental Engineering and Management Journal, 17(11), 2999-3005.

Ilieș, D. C., Oneț A., Marcu F. M., Gaceu O. R., Timar A., Baias Ș., Ilieș A., Herman G. V., Costea M, Țepelea M., Josan I., Wendt J., (2018c), Investigations Regarding The Air Quality In The Historic Wooden Church In Oradea City, Romania. Environmental Engineering and Management Journal, 17(11), 2731-2739.

Indrie, L., Oana, D., Ilieş, M., Ilieş, D. C., Lincu, A., Ilieş, A., Ş. Baias, G. Herman, A Onet, M. Costea, F. Marcu, L. Burta \& Oana I., (2019), Indoor air quality of museums and conservation of textiles art works. Case study: Salacea Museum House, Romania. Industria Textila, 70(1), 88-93.

Kochev, A. G., (2017), The influence of external aerodynamics on the microclimate of Orthodox churches: research monograph; Nizhny Novgorod: Novgorod State University of Architecture and Civil Engineering, 188 p., ISBN 978-5-528-00192-0.

Mihăilescu, M., Constantinescu, C., Camui, I., (2002), Influenţa unor factori de mediu asupra monumentelor istorice (The influence of environmental factors upon the historic monuments). In $8^{\text {th }}$ International Conference Târgu Jiu.

Necula, E. T., (2016), Teza de doctorat, Biserici de lemn buzoiene, stare de conservare şi programe de valorificare, Târgoviște (Wooden churches from Buzau, conservation and valorization. Ph.D. thesis), http://scoaladoctorala.valahia.ro, 14.12.2017, 19:10.

Onet, A., Ilies, D. C., Buhas, S., Rahota, D., Ilies, A., Baias, S., Marcu F. \& Herman, G. V., (2018), Microbial Air Contamination in Indoor Environment of University Sports Hall. Journal of Environmental Protection and Ecology, 19(2), 694-703.

Rosin, P., Adamatzky, A., Sun, X. (Eds.), (2014), Cellular automata in image processing and geometry. Springer International Publishing.

Sadłowska-Sałęga, A., \& Radoń, J., (2014), Experimental and theoretical study of microclimate in historical church in Wiśniowa. Czasopismo Techniczne, 3-B(8), 415-423.

Seppänen, O., Fisk, W.J., Lei, Q.H., (2006), Ventilation and performance in office work. Indoor Air, 16, 28-36.

Simileanu, M., Maracineanu, W., Deciu, C., Striber, J., \& Radvan, R., (2006), A complex portable optoelectronic setup for on-site interventions: case studies. In Seventh International Conference on Vibration Measurements by Laser Techniques: Advances and Applications (Vol. 6345, p. 63450U). International Society for Optics and Photonics.

Varas-Muriel, M. J., Fort, R., Martínez-Garrido, M. I., Zornoza-Indart, A., López-Arce, P., (2014), Fluctuations in the indoor environment in Spanish rural churches and their effects on heritage conservation: Hygro-thermal and $\mathrm{CO}_{2}$ conditions monitoring. Building and Environment, 82, 97-109.

Vasilescu, K., (2016), Documentar Biserici de lemn din Romania (Wooden churches from Romania), DVD, Studio East Movies.

Submitted:

17.08.2019
Revised:

04.09.2019
Accepted and published online 06.09.2019 